\title{
PEMATANGAN GONAD INDUK UDANG PUTIH (Penaeus indicus) ASAL TAMBAK DENGAN BEBERAPA METODE ABLASI TANGKAI MATA
}

\author{
Samuel Lante") dan Haryanti")
}

\begin{abstract}
ABSTRAK
Proses pematangan induk udang putih Penaeus indicus asal tambak masih sangat lambat sehingga perlu dilakukan perangsangan pematangannya. Satu di antara metode perangsangan pematangan gonad adalah dengan rangsangan hormonal melalui ablasi tangkai mata. Penelitian metode ablasi tangkai mata yang berbeda dilakukan terhadap induk udang putih (Penaeus indicus) asal tambak, dengan tujuan mendapatkan metode yang efektif bagi pematangan gonad udang putih asal tambak dalam arti dapat meningkatkan pemijahan, jumlah, diameter dan daya tetas telur.

Menggunakan rancangan acak lengkap dengan perlakuan pemotongan tangkai mata, pengikatan tangkai mata. injeksi alkohol pada tangkai mata. dan tanpa pemotongan tangkai mata (kontrol), induk dipelihara selama 14 hari. Pemberian pakan segar berupa campuran cumicumi. kijing. dan pelet dengan perbandingan $2: 1: 1$ sebanyak $5 \%$ dan $10 \%$ bobot ikan masing. masing pada pagi dan sore hari. Hasil yang diperoleh menunjukkan bahwa jumlah, diameter, dan daya tetas telur tidak dipengaruhi oleh perlakuan cara ablasi mata $(P>0,05)$ induk udang putih (Penaeus indicus) asal tambak.
\end{abstract}

\section{ABSTRACT: Gonadal maturation of pond reared white shrimp Penaeus indicus spawners applying different methods of eyestalk ablation. By: Samuel} Lante and Haryanti.

Success of gonadal maturation of pond-reared white shrimp spawner was still law, and therefore a better stimulation technique was needed. One method for stimulating gonad maturation of white shrimp was hormonal manipulation through eyestalk ablation. Experiments were conducted on gonad maturation of pond reared spawners of white srimp Penaeus indicus applying different methods of eyestalk ablation. The purpose of this experiment was to evaluate the effects of these methods on fecundity, diameter of eggs, spawning, and hatching rates of shrimp spawners.

The experimental design used was a completely randomized design (CRD) with four treatments i.e eyestalk ablation, eyestalk alcohol injection, eyestalk tying, and without eyestalk ablation. The spawners were fed at 15\% body weight daily with mixture of squid, mussel, and pellet at 2:1:1 ratio. Food was given twice a day i.e $5 \%$ in the morning and $10 \%$ in the afternoon. Result of the experiments showed that fecundity, diameter of eggs, and hatching rates were not significantly affected $(P>0.05)$ by eyestalk ablation treatments.

KEYWORDS: Penaeus indicus; eyestalk ablation.

\section{PENDAHULUAN}

Di Indonesia penggunaan induk udang putih Penaeus indicus asal tambak untuk pembenihan belum dilakukan, disebabkan karena benih yang cukup banyak tersedia di alam (Mudjiman, 1981). Tetapi karena akhir-akhir ini timbul berbagai macam kasus seperti penyakit dan pencemaran lingkungan yang menyebabkan menurunnya produksi udang, maka sebagian petani tambak mengalihkan usaha budidaya udang putih Penaeus indicus yang lebih tahan dan kuat terhadap perubahan kondisi perairan, tidak mudah stres, dapat mengadaptasi kisaran suhu dan tingkat kelangsungan hidup yang lebih tinggi. Untuk itu bila hanya mengandalkan

*) Peneliti pada Loka Penelitian Perikanan Pantai Gondol, Bali 
benur dari tangkapan alam tentu mengalami kekurangan. Kejadian di atas memacu pengusaha panti benih untuk memproduksi benur udang putih sebagai sumber benih bagi tambak.

Lim et al. (1987) menyatakan bahwa di Singapura pembenihan udang putih secara komersial dimulai sejak tahun 1980, sedangkan Makinouchi dan Primavera (1987) menyatakan bahwa di Philipina dan negara Asia lainnya, udang putih potensial untuk menggantikan kebutuhan udang windu jika persediaan menurun. Staples et al.(1984), menyatakan bahwa Penaeus merguiensis asal laut matang gonad pada umur 8 (delapan) bulan dan memijah pada kedalaman 18-24 meter, sedangkan Lim et al. (1987) mengatakan bahwa Penaeus indicus matang gonad pada umur 10 (sepuluh) bulan dan memijah pada kedalaman 25 meter.

Untuk mengantisipasi kebutuhan benur bagi petambak dalam jumlah besar, salah satu cara adalah memproduksi benur di panti benih baik induk udang putih yang berasal dari laut maupun asal tambak. Panti benih aneka jenis udang dan ikan di Loka Penelitian Perikanan Pantai Gondol, mulai merintis pembenihan udang putih yang berasal dari tambak. Hal ini dilakukan karena di samping udang putih asal tambak mudah diperoleh juga harganya murah.

Berdasarkan informasi di atas, maka dilakukan penelitian pematangan gonad udang putih asal tambak dengan berbagai metode ablasi mata, yang bertujuan untuk mendapatkan metode yang efektif terhadap pematangan gonad udang putih asal tambak, untuk meningkatkan pemijahan, jumlah, mutu telur dan larvanya.

\section{BAHAN DAN METODE}

Sebagai hewan uji adalah induk udang putih asal instalasi Tambak Percobaan Negara yang berumur sekitar 6 bulan yang kemudian dipindahkan ke Loka Penelitian Perikanan Pantai Gondol, untuk diaklimasi selama 1-2 minggu dalam bak berukuran $5 \mathrm{~m}^{3}$. Kisaran bobot induk adalah 21-31,5 g/ind. untuk induk betina dan 16 23,5 g/ind untuk induk jantan. Jumlah induk yang digunakan masing-masing 25 pasang, dengan tingkat kematangan gonad awal adalah nol.
Wadah penelitian adalah 4 buah bak beton berbentuk silinder dengan ukuran $(3,27 \mathrm{~m}$ x 0,75 m) atau volume $8 \mathrm{~m}^{3}$ sebagai bak pematangan, dan bak serat kaca berbentuk kerucut volume 300 liter sebagai bak pemijahan. Bak pematangan meng-gunakan sistem air mengalir dengan pergantian air sebanyak $100-150 \%$ per hari dan dilengkapi dengan aerasi sebagai sumber oksigen. Penyinar-an diberikan sebanyak 2-3 lux selama pemeli-haraan.

Sebagai perlakuan adalah (A) pemotongan tangkai mata, (B) pengikatan tangkai mata, Makinouchi dan Primavera (1987), dan (C) injeksi alkohol pada tangkai mata sebanyak $(0,005 \mathrm{~mL})$ serta (D) tanpa pemotongan tangkai mata (kontrol). Setelah matang gonad tingkat IV berdasarkan Lim et al. (1987), induk udang kemudian dipindahkan ke dalam bak pemijahan. Setelah bertelur, induk udang dikembalikan ke dalam bak pematangan. Perhitungan jumlah dan daya tetas telur dilakukan berdasarkan Lim et al. (1987) dan pengamatan diameter telur dilakukan dengan mikrometer.

Selama proses pematangan gonad, induk udang diberi pakan berupa campuran antara cumi-cumi, kijing, dan pelet komersial dengan perbandingan $2: 1: 1$. Jumlah pemberian $10-15 \%$ dari bobot total biomassa per hari diberikan pada pagi $(5 \%)$ dan sore hari $(10 \%)$.

Peubah biologik yang diamati adalah jumlah induk yang memijah, jumlah dan diameter serta daya tetas telur. Data dianalisis dengan menggunakan sidik ragam rancangan acak lengkap. Pengamatan peubah kualitas air yang meliputi suhu, salinitas, $\mathrm{pH}$, dan intensitas cahaya pada bak pematangan dilakukan setiap pagi dan sore hari. Adapun komposisi pakan yang diberikan adalah kandungan protein $40,2 \%$; lemak $7,2 \%$; abu $15,5 \%$, kandungan air 9,1\%; dan lain-lain $28,0 \%$.

\section{HASIL DAN PEMBAHASAN}

Hasil pengamatan panjang karapak, panjang badan, bobot badan, persentase induk yang bertelur, jumlah, diameter, dan daya tetas telur selama penelitian disajikan pada Tabel 1 . 
Tabel 1. Rataan panjang karapas, panjang badan dan bobot badan, tingkat pemijahan, jumlah dan diameter telur, dan daya tetas telur selama pengamatan pada beberapa perlakuan ablasi.

Table 1. Average carapax length of shrimp, body length, body weight, percentage of spawning, number, and diameter of eggs, and hatching rate obtained from shrimp spawners treated with different eyestalk ablation methods.

\begin{tabular}{|c|c|c|c|c|c|c|c|}
\hline $\begin{array}{c}\text { Perlakuan } \\
\text { Treatments }\end{array}$ & $\begin{array}{c}\text { Panjang } \\
\text { karapas } \\
\text { Carapax } \\
\text { length } \\
(\mathrm{mm}) \\
\end{array}$ & $\begin{array}{c}\text { Panjang } \\
\text { badan } \\
\text { Body } \\
\text { length } \\
(\mathbf{m m}) \\
\end{array}$ & $\begin{array}{c}\text { Bobot } \\
\text { badan } \\
\text { Body } \\
\text { Weight } \\
\text { (g) } \\
\end{array}$ & $\begin{array}{c}\text { Jumlah telur } \\
\text { Number of egg } \\
\text { (PCs) }\end{array}$ & $\begin{array}{c}\text { Diameter } \\
\text { telur } \\
\text { Diameter } \\
\text { of egg } \\
\text { (um) } \\
\end{array}$ & $\begin{array}{c}\text { Daya tetas } \\
\text { Hatching } \\
\text { rate } \\
(\%) \\
\end{array}$ & $\begin{array}{c}\text { Tingkat } \\
\text { pemijahan } \\
\text { Spawning } \\
\text { rate } \\
(\%) \\
\end{array}$ \\
\hline $\begin{array}{l}\text { Tanpa ablasi } \\
\text { Unablated } \\
\text { eyestalk }\end{array}$ & $32.3 \pm 1.79$ & $140 \pm 11.68$ & $25.6 \pm 2.38$ & $64.634 \pm 20.558^{a}$ & $285.2 \pm 8.61^{b}$ & $50.43 \pm 19.93^{c}$ & 20 \\
\hline $\begin{array}{l}\text { Ablasi } \\
\text { Ablated } \\
\text { eyestalk }\end{array}$ & $33.1 \pm 1.78$ & $124 \pm 6.37$ & $26.6 \pm 3.33$ & $56.463 \pm 19.343^{a}$ & $282.9 \pm 8.32^{b}$ & $39.02 \pm 20.27^{c}$ & 64 \\
\hline $\begin{array}{l}\text { Penyuntikan } \\
\text { alkohol } \\
\text { Alcohol } \\
\text { injected } \\
\text { eyestalk }\end{array}$ & $32.5 \pm 1.76$ & $118 \pm 3.62$ & $24.3 \pm 2.62$ & $55.924 \pm 19.626^{\mathrm{a}}$ & $285.4 \pm 5.83^{b}$ & $51.02 \pm 12.14^{\mathrm{c}}$ & 24 \\
\hline $\begin{array}{l}\text { Pengikatan } \\
\text { tangkai mata } \\
\text { Tied eyestalk }\end{array}$ & $32.4 \pm 3.52$ & $122 \pm 4.62$ & $27.3 \pm 3.07$ & $56.319 \pm 20.117^{a}$ & $284.9 \pm 9.29^{b}$ & $40.03 \pm 14.88^{\circ}$ & 60 \\
\hline
\end{tabular}

Angka yang diikuti huruf yang sama menunjukkan tidak berbeda nyata (Superscript in columns followed by the same letter are not significantly different $)(\mathrm{P}>0.05)$

Hasil penelitian menunjukkan bahwa pemotongan tangkai mata memberikan persentase jumlah induk memijah lebih tinggi, menyusul pengikatan tangkai mata (Tabel 1). Hal ini kemungkinan disebabkan pemotongan tangkai mata mempengaruhi perkembangan ovocytus, akibatnya telur yang dihasilkan juga lebih kecil bila dibandingkan dengan tanpa pemotongan tangkai mata. Nurjana (1979) mengatakan bahwa ablasi berpengaruh positif terhadap fisiologis, sedangkan Laufer dan Landau (1991) mengemukakan bahwa ablasi tangkai mata dapat meningkatkan perkembangan ovari. Juga ablasi mata pada Penaeus canaliculatus dapat meningkatkan pemijahan, jumlah dan daya tetas (Choy, 1987).

Jumlah telur yang dihasilkan pada masingmasing perlakuan (Tabel 1) adalah hampir sama karena pemberian pakan yang baik dan pengelolaan kualitas air serta waktu penyinaran yang optimal. Nurdjana (1986) menyatakan bahwa kualitas dan kuantitas makanan yang diberikan mempengaruhi jumlah telur yang dihasilkan, sedangkan Aquacop (1977) dalam Nurdjana (1986) berpendapat bahwa perbandingan satu jantan dan satu betina menghasilkan jumlah telur yang sempurna. Hasil penelitian ini sesuai dengan para peneliti pendahulu yang mengatakan bahwa jumlah telur yang dihasilkan Penaeus indicus dengan rata-rata bobot badan 25 gram sebanyak 25.000-80.000 butir (Quackenbush, 1991; Bagarinao et al. 1995; Lim et al., 1987), jumlah telur yang dihasilkan dari induk udang windu tergantung ukuran induk (Lante et al., 1993; Tridjoko dan Sutarmat, 1994).

Hasil penelitian menunjukkan bahwa diameter telur masing-masing perlakuan tidak berbeda nyata pada $(P>0,05)$. Namun demikian diameter telur udang putih yang dicapai pada penelitian ini menyerupai hasil penelitian Quackenbush(1991) yang mengemukakan bahwa udang putih memiliki diameter telur 280-300 $\mu \mathrm{m}$. 
Daya tetas telur merupakan salah satu kriteria bahwa telur yang dihasilkan baik atau buruk. Hasil penelitian menunjukkan bahwa daya tetas yang diperoleh pada masing-masing perlakuan tidak menunjukkan perbedaan. Hal ini sesuai dengan hasil analisis statistik yang menunjukkan bahwa daya tetas tidak berbeda nyata pada $\mathrm{P}>0,05$ (Table 1). Hasil ini berbeda dengan Emmerson et al. (1983) dan Primavera et al. (1982), yang menyatakan adanya perbedaan nyata antara pematangan dengan ablasi dan tanpa ablasi induk udang putih (Penaeus indicus) asal laut. Diperolehnya hasil yang berbeda nyata pada pematangan induk udang asal laut, diduga disebabkan oleh tingginya tingkat heterogenitas induk udang betina maupun udang jantan yang digunakan sebagai hewan uji misalnya dalam hal lokasi penangkapan dan sifat genetis, dan jenis makanannya berbeda dengan induk asal tambak yang lebih homogen oleh karena lingkungan pemeliharaan, jenis makanan dan umur yang relatif sama.

Hasil pengamatan kualitas air selama penelitian menunjukkan suhu air $27,5-30,5^{\circ} \mathrm{C}$, $\mathrm{pH}$ $7,80-8,60$, dan salinitas $32-33$ ppt serta intensitas cahaya 0,5-2,0 lux, yang masih berada dalam kisaran yang layak mendukung proses pematangan gonad udang putih (Penaeus indicus).

\section{KESIMPULAN}

1. Persentase jumlah induk yang memijah tertinggi $64 \%$ diperoleh pada pemotongan tangkai mata menyusul $60 \%$ pada pengikatan tangkai mata.

2. Daya tetas telur yang diperoleh dari pematangan gonad udang putih (Penaeus indicus) asal tambak dengan berbagai ablasi mata tidak berbeda nyata.

\section{DAFTAR PUSTAKA}

Bagarinao, T.U.; N.B. Solis: W.R. Villaver; and A.C.Villaluz. 1995. Important fish and shrimp fry in Philippine coastal waters: Identification, collection and handling. Aquaculture extension manual No.10. Aquacult. Dept. SEAFDEC., Tigbauan, Iloilo. 52p.

Choy, S.C. 1987. Growth and reproduction of eyestalk ablated Penaeus canaliculatus (Olivier, 1811) (Crustacea: Penaeidae). J. Exp. Mar. Biol. Ecol. 112:93-107.
Emmerson, W.D.; D.P. Hayes; and M. Ngonyame. 1983. Growth and maturation of Penaeus Indicus under blue and green light. S.Afr.Tijdskr.Dierk. 18:71-75.

Haryanti. 1995. Keragaan benih udang putih Penaeus indicus turunan pertama dan ke dua. Dalam Buku Panduan dan Abstrak Seminar Biologi XIV dan Kongres Nasional Biologi XI. Universitas Indonesia, Depok, 24-27 Juli 1995.

Lante, S.; Tridjoko; T. Sutarmat; J.H. Hutapea; dan S. Makinouchi.1993. Pengaruh tingkat salinitas terhadap pematangan gonad dan pemijahan induk udang windu, Penaeus monodon asal tambak. J. Penel.Budidaya Pantai 9(2):9-16.

Laufer, H. and M. Landau. 1991. Endocrine control of reproduction in shrimp and other crustacea. In Frontiers of Shrimp Research. Developments in Aquaculture and Fisheries Science (22):65-81.

Lim.l.C.; H.H. Heng; and L.Cheong. 1987. Manual on breeding of Banana Prawn. Primary Production Department. Republik of Singapore. 62p.

Makinouchi, S. and J.H. Primavera. 1987. Maturation and spawning of Penaeus indicus using different ablation methods, Aquaculture, 62:73-81

Mudjiman, A. 1981. Budidaya udang putih. Seri Perikanan, Penebar Swadaya. 45 hal.

Nurjana, M.L. 1979. Produksi massal induk matang telur udang penaeid melalui ablasi mata. Bull. Warta Mina 3(6):24-27.

Nurdjana, M.L. 1986. Pengaruh ablasi mata terhadap perkembangan telur dan embrio serta larva udang windu (Penaeus monodon Fab). Disertasi. Fakultas Pasca Sarjana UGM, Yogyakarta. 470 hal.

Primavera, J.H.; T.Young; and C.De los Reyes. 1982. Survival, maturation, fecundity and hatching rates of unablated and ablated Penaeus indicus H.M. Edards from brackishwater ponds. Proc. Symp. Coastal aquaculture, 1:48-54

Quackenbush, L.S. 1991. Regulation of vetellogenesis in Penaeid shrimp. In Frontiers of Shrimp Research, Developments in Aquaculture and Fisheries Science (22) :65-81.

Tridjoko dan T. Sutarmat. 1994. Pengamatan Kematangan Gonad dan Kualitas Telur Udang windu Penaeus monodon asal tambak pada tingkat umur yang berbeda. J. Penel. Budidaya Pantai, $10(1) 1-8$

Staples.D.J; W.Dall; and D.J.Vance. 1984. Catch prediction of the banana prawn, Penaels merguensis, in the south eastern Gulf of Carpentaria (259-267 p). In Fishery News Books Limited Farnham Surrey, England. 308 p. 